Matej Šekli

University of Ljubljana*

ZRC SAZU, Ljubljana
UDK 811.163'373.21:811.13

DOI: 10.4312/linguistica.55.1.103-114

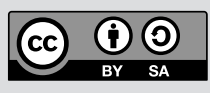

\title{
OLD ROMANCE PLACE NAMES IN EARLY SOUTH SLAVIC AND LATE PROTO-SLAVIC SOUND CHANGES ${ }^{1}$
}

\section{INTRODUCTION}

The article analyses Old Romance geographical names borrowed and integrated into early South Slavic. The late Proto-Slavic sound changes which were still operative during the first Romance-Slavic language contacts after the settling of the Slavs in the Balkan Peninsula, the Pannonian Basin and eastern Alps in the second half of the $6^{\text {th }}$ century and the beginning of the $7^{\text {th }}$ century will be categorized and chronologically ordered with the help of Romance-Slavic substitutional phonology.

\subsection{Slavic migration to the Balkan Peninsula, the Pannonian Basin and the eastern Alps}

The most likely answer to the Proto-Slavic homeland question seems to be the socalled North-Carpathian theory, which argues rather convincingly that the homeland of the Slavs should be placed to the North of the Carpathian Mountains, i.e. the North-Carpathian basin. The approximate borders of this language community would be the upper course of the Dniester and Vistula rivers in the West, the Pripyat river in the North, and the middle course of the Dnieper in the East (Gimbutas 1971: 80; Udolph 1979: 619-623). It is generally believed that the Slavic migration towards the North-East, North-West and South-West should be placed at around 500 AD. This migration wave did not include a south-eastern movement, however. As can be predicted, the colonization of the new territory resulted in more or less direct contact with the different non-Slavic languages.

The Slavs began their south-western move towards the eastern Carpathians together with the Avars. They reached the Balkan Peninsula, the Pannonian Basin and the eastern Alps in the $6^{\text {th }}$ century AD. In the southern part of the Balkans they first came into contact with Greek, while in the rest of the Balkans, the Pannonian plain and the eastern Alpine region they encountered the Old Romance stratum. As far as the eastern Alps are concerned, the $8^{\text {th }}$ century was dominated by the equally extensive interaction

* Oddelek za slavistiko/Department of Slavic Languages, Filozofska fakulteta, Aškerčeva 2, 1000 Ljubljana, Slovenia; matej.sekli@ff.uni-lj.si

1 A more comprehensive account of the Slavic language contact with the non-Slavic idioms is presented in Šekli 2014: 201-300. For the Slovene version of the article cf. Šekli 2015. 
with Old High German (Old Bavarian), while the Hungarian-Slavic contacts in the Pannonian Basin are not older than the $9^{\text {th }}$ century AD.

The Slavs settled the newly conquered territories of South-Eastern Europe in the second half of the $6^{\text {th }}$ century. At the start of the $7^{\text {th }}$ century, during the rule of Gregory the First (590-604 AD), the colonization wave had already reached as far as the Adriatic coast (Kos 1955: 44-49). During the colonization of the Romance/Romanized territory several place names were borrowed into Slavic from the Romance speaking population, primarily but not exclusively those of the near coastal area. These integrations usually involve the adoption of Romance names for the strategically more prominent geographical objects such as larger rivers and urban settlements.

\subsection{Balkan Romance vs. Alpine Romance}

At the time of the Slavic occupation of the south-eastern part of the Romance linguistic area the Slavs conquered the territory to the north of the Romance-Greek language border also known as the Jireček line. Note that Latin inscriptions of the Balkan provinces reach in the south the ancient towns of Ulpiana/Ulpianum ( $8 \mathrm{~km}$ to the south of presentday Priština), Scupi (4 km to the north-east of present-day Skopje city centre), Naissus (present day Niš in Serbia) and Remesiana (present-day Bela Palanka in Serbia), in Thracia Superior, and a number of ancient settlements around the Danube delta in Thracia Inferior (Solta 1980: 64-65).

By the time of the earliest Slavic-Romance contacts ( $6^{\text {th }}$ century AD) two clearly distinguishable Old Romance geolects had already developed from Vulgar Latin, i.e. North-West Romance (the predecessor of Alpine, North-Italic or Gallo-Italic, Gallic and Iberian Romance) and South-East Romance (the direct ancestor of Balkan Romance and Central-South Italic Romance). The distinguishing isogloss dividing the two dialects runs vertically through the Apennine Mountains, following the socalled La Spezia-Rimini line, and horizontally through present-day Koper/Capodistria, Solkan and Villach/Beljak. ${ }^{2}$

The defining characteristics of South-East Romance are the preservation of Latin voiceless stops in voiced environment (i.e. between vowels or between a vowel and a resonant) and the loss of final $-s$, while the diametrically opposed situation is true of North-West Romance: lenition (voicing $\rightarrow$ spirantization $\rightarrow$ loss) of Latin voiceless stops in voiced environments and the preservation of Latin final $-s$. Examples: Lat. Asg rota $(m)$ 'wheel' > Standard Italian ruota, Romanian roată vs. Friulian ruede, Venetian Italian roda, rioda, Sardinian roda, Catalan roda, Spanish rueda, Portuguese roda, Old French rode $>$ French roue; Lat. 2sg pres. ind. cantās 'you sing' > Friulian cjantis, Sardinian cantas, Catalan cantes, Spanish cantas, Portuguese cantas, Occitan cantas, French chantes vs. Standard Italian canti, Romanian cânți; Lat. Apl rotās 'wheels' > Friulian ruedis, Sardinian rodas, Catalan rodes, Spanish ruedas, Portuguese rodas,

2 However, Trieste/Trst and Gail/Zilja lie to the west of the Koper/Capodistria-Solkan-Villach/ Beljak isogloss but clearly display the phonetic characteristics typical of South-East Romance (Balk. Rom. *Tergeste $\rightarrow$ S1. *Tbrzbstъ; Balk. Rom. *Gīla $\rightarrow$ Sl. *3iĺa). 
Occitan rodas, Old French rodes $>$ French roues vs. Standard Italian ruote, Romanian roți) (Wartburg 1950: 32; Skubic 1989: 97, 100).

On the other hand, the Koper/Capodistria-Solkan-Villach/Beljak isogloss separates the two linguistic areas with a different set of reflexes for plain velars $* k$, * $g$ before front vowels. Accordingly, Slavic substitutions $*_{c}, *_{z}$ normally occur to the west of this line (Lat. Asg cìvitāte (m) 'town'> Rom. *Kevẹtāte > Alp. Rom. *Cẹvẹdāde $(>$ Friulian Cividât $) \rightarrow$ Sl. ${ }^{*} \check{C} b v b d a d b>$ dial. Sln. (Natisone/Nadiža) Čavdàd 'a city in Friuli; Standard Sln. Čedad, Friulian Cividât, Italian Cividale'; Lat. Asg silice (m) 'hard stone, rock, flint' $\rightarrow$ Asg *silicētu $(m)$ 'where hard stone, rock, flint is' $>$ Rom. *Selekeẹtu > Alp. Rom. *Sẹlẹgẹdu > *Sẹlȩ̣ẹedu $\rightarrow$ Sl. *Sblbžidz > dial. Sln. (Soča/ Isonzo) Sužìd 'a place in the Upper Soča Valley'). The reflexes ${ }^{*} c$, *3, which are the outcomes of the second Slavic palatalization of velars (cf. 2.6), are only found to the east of the isogloss. ${ }^{3}$

In the south, Slavic came into direct contact with both Balkan Romance (Lat. acētum 'vinegar' > Rom. *akẹtu > Balk. Rom. *akẹttu $\rightarrow$ PSl. *okbtb > *ocbtъ 'vinegar') and Alpine Romance (Lat. Asg cruce $(m)$ 'cross' > Rom. *krọke > Alp. Rom. *krọge > *krō̧̧̌ $\rightarrow$ PSl. *križb 'cross'). The borrowing of common and proper names therefore progresses from both sources. Note that if the Old Romance source has no voiceless stops occurring in a voiced environment and/or no $* k^{E}$, ${ }^{*} g^{E}$ sequences (e.g. Lat. Apl Kalendās 'first day of the month' > Rom. *kalendās $\rightarrow$ PSl. *kolęda 'New Year, celebration of the New Year'), the distinction between the two sources is not always easily disambiguated.

\section{LATE PROTO-SLAVIC SOUND CHANGES}

The following were late Proto-Slavic sound changes (listed in approximate chronological order): loss of final consonants, simplification of consonant clusters, development of prothetic consonants, first regressive palatalization of velars, simplification of $j$-clusters, delabialization of rounded vowels (umlaut), monophthongization, second regressive palatalization of velars, the rise of nasal vowels (nasalization), progressive palatalization of velars, delabialization of $* \bar{u}_{1}>*_{y}$, labialization of $* a>*_{o}$, reduction of vowels $\left(*_{i}, * u *_{b}, *_{b}\right)$ (Shevelov 1964: 187-390; Šekli 2014: 201-300). The majority of these sound changes were still operative at the time of the earliest RomanceSlavic language contacts, but some postdate the earliest phases of lexical and toponymic borrowing.

\subsection{Simplification of consonant clusters}

The Old Romance consonant cluster *ps correspondes by South Slavic *s: Rom. *ps $\rightarrow$ Sl. *s (Lat. Apsarum $>$ Balk. Rom. *Apsaru $\rightarrow$ Sl. *Osorb $>$ Čak. Osör 'a town on

3 For a discussion of the phenomenon cf. Skok 1926: 386; Ramovš 1926/27: 154-155, 160-165; Šturm 1927: 45-47, 1928: 22-24; Grad 1958, 1969; Skubic 1989: 101; Furlan 2002: 32-33. See Repanšek 2014 for a recent reappraisal of the data. 
the island of Cres'; Lat. *Sampsichum $>$ Balk. Rom. *Sampsiku $\rightarrow$ Sl. *SQsbkb $>$ Čak. Süsak 'an island in the Gulf of Kvarner'). This seems to confirm the fact that the ProtoSlavic simplification of consonant clusters was still an ongoing process at the time of the borrowing: PSl. ${ }^{*} p s>*_{s}$.

\subsection{Development of prothetic consonants}

The integrated word-initial $* \bar{u}$ - nearly always generates a prothetic consonant $*_{v \text { - in }}$ South Slavic: Rom. ${ }^{*} \bar{u}-\rightarrow$ Sl. ${ }^{*} u \bar{u}->*^{*} y$ - (Lat. Utinum $>$ Alp. Rom. ${ }^{*} \bar{U} d e n u$ ( $>$ Friulian Udin $) \rightarrow$ Sl. *(V)ydbnz $>$ Dial. Sln. Vidon 'a city in Friuli; Standard Sln. Videm, Friulian Udin, Italian Udine'). ${ }^{4}$ This means that at the time of the borrowing the development of the Proto-Slavic prothetic ${ }^{*} u$ - in front of word-initial high back vowels ${ }^{*} \bar{u}$ - and ${ }^{*} u$ - was

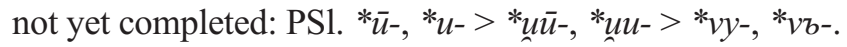

\subsection{Simplification of $\boldsymbol{j}$-clusters}

Proto-Slavic palatal consonants ${ }^{*} C^{\prime}$ are systematically substituted for Old Romance consonant clusters ${ }^{*} C i$ : Rom. ${ }^{*} C i \rightarrow$ Sl. ${ }^{*} C^{\prime}$ (Lat. Durachium $>$ Balk. Rom. ${ }^{*}$ Dorākiu $\rightarrow$ S1. *Dъračb $>$ Štok. Drâč 'Durrës, a city at the Adriatic coast in Albania'; Lat. *Plagia $(\leftarrow$ Greek $\pi \lambda \dot{\alpha} \gamma l o \varsigma$ 'oblique, inclined') $>$ Balk. Rom. *Plāgia $\rightarrow$ Sl. *Plaža $>$ Čak. Pläža 'a town on the island of Hvar'; Lat. Arsia $>$ Balk. Rom. *Arsia $\rightarrow$ Sl. *Orša $>$ Čak. Räša 'a river in Istria'; Lat. Carnium $>$ Balk. Rom. *Karniu $\rightarrow$ Sl. *Korńb > Sln. Kránj 'a town in the Gorenjska/Upper Carniola region'; Rom. *Castelliōne $(m)>$ Balk. Rom. Asg *Kasteliộne $\rightarrow$ Sl. *Kostblunz > Čak. Košljûn 'a small island in the Punat Bay on the island of Krk'; Lat. Tragurium $>$ Balk. Rom. *Tragūrinu $\rightarrow$ Sl. *Trogyŕb $>$ Čak. Trogĩr 'a town in Southern Dalmatia'). The Proto-Slavic simplification of $j$-clusters evidently took place after the borrowing of these place names into South Slavic.

\subsection{Delabialization of rounded vowels (umlaut)}

Slavic appears to have delabialized all rounded vowels of the $u$-type after palatal consonants and $r:{ }^{5}$ Rom. ${ }^{*} C^{\prime} O /{ }^{*} r O \rightarrow \mathrm{Sl}$. ${ }^{*} C^{\prime} E /{ }^{*} r E$ (Lat. Iüdaeus 'Jude' $>$ Rom. * ${ }^{*} \bar{u} d \bar{e} u s$ $(?) \rightarrow$ Sl. *Žydı > *Židъ 'Jude' (> OCS Žid-inъ 'Jude'); Lat. crux 'cross', Asg crucem $>$ Rom. *krộke > Alp. Rom. *krọge > *krọ̄je $\rightarrow$ PSl. *kryžb > *križb 'cross' (> OCS križb 'cross'). Among the place names which further attest to such a process there is, for instance, the exonym Sl. *Rims 'Rome' (Lat. Rōma $>$ Rom. *Rōma $\rightarrow$ Sl. *Ryms $>$ * $\operatorname{Rimb}(>$ OCS Rimb)).

4 From the lexical fond cf. Lat. hortus 'garden' > Balk. Rom. * ortu $\rightarrow$ Sl. *(v) brtb 'garden' (> OCS *vrbtr, Sln. vrt).

5 It is less probable that the forms such as *križb and *Rims reflect early $\left(7^{\text {th }}-8^{\text {th }}\right)$ South-Slavic phonology. Accordingly, the Proto-Slavic *y would have been decentralized rather early in the south (cf. Bezlaj 1995: 180). However, the phonetic distinction between $*_{y}$ and $*_{i}$ in South Slavic is still present in the second half of the $9^{\text {th }}$ century by Old Church Slavic (863-885) and the subsequent merger cannot in fact be earlier than the second half of the $10^{\text {th }}$ century as evidenced by the Freising Monuments (972-1039 AD). 


\subsection{Monophthongization}

Proto-Slavic tautosyllabic sequences ${ }^{*} o j,{ }^{*} o v$ are substituted for the corresponding Old Romance diphthongs *ai, *au: Rom. *aiC, *auC $\rightarrow \mathrm{Sl}$. ${ }^{*} o j C$, *ovC (Lat. *Laurentium $>$ Balk. Rom. *Laurentiu $>$ *Laurenču $\rightarrow$ Sl. *Lovręčb $>$ Čak. Lovrëč 'a town in Istria'; Lat. *Tauriana $>$ Balk. Rom. *Tauriāna $\rightarrow$ Sl. *Tovranb $>$ Štok. Tovrljan 'a river in the vicinity of Niš'). ${ }^{6}$ This phenomenon attests to the likelihood of the integration of the place names largely postdating monophthongization.

\subsection{Second regressive palatalization of velars}

Notably, Old Romance velar stops $* k, * g$ before front vowels were not integrated into South Slavic as $*_{c}$, ${ }^{*} z$, but as $*_{c}$ and $*_{3}$ : Rom. ${ }^{*} k^{E},{ }^{*} g^{E} \rightarrow$ Sl. ${ }^{*} c,{ }^{*}$ (Lat. Celeia $>$ Rom. *Kelēia > Balk. Rom. *Kelẹ̣ia $\rightarrow$ Sl. *Celbje $>$ Sln. Célje 'a town in the south

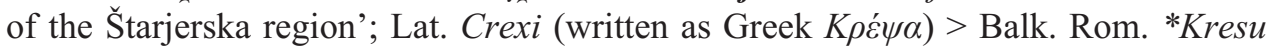
$\geq{ }^{*}$ Kersu (after metathesis *re $\geq$ er) $(>$ Dalmatian *Kerso $\rightarrow$ Italian Cherso) $\rightarrow$ Sl. *Cersz > NW Čak. Crès 'an island in the Gulf of Kvarner'; Lat. Centōna > Balk. Rom. *Kentọna $\rightarrow$ Sl. *Cętyna $>$ Štok. Cètina 'a river in Southern Dalmatia'; Lat. Asg Cìvitāte $(m)>$ Balk. Rom. *Kẹvẹtāte $\rightarrow$ Sl. ${ }^{*}$ Cbbbtatb $>$ Štok. Càptat, Càvtat 'a town in Southern Dalmatia'; Balk. Rom. *Gīla $\rightarrow$ Sl. * Bila $>$ Sln. Zilja 'a river in the eastern Alps; Germ. Gail'; Lat. Genta $>$ Balk. Rom. ${ }^{*}$ Genta $\rightarrow$ Sl. *3eta $>$ Štok. Zeta 'a river in Montenegro'). These data indirectly provide important evidence in support of the hypothesis that by the time of extensive Romance-Slavic language contacts the first regressive palatalization of velars had already been concluded but that the second Slavic regressive palatalization of velars was still an ongoing change (evidently in front of all (new) front vowels).

\subsection{Rise of nasal vowels}

The South Slavic reflexes of the Old Romance sequences ${ }^{*} E N C$, ${ }^{*} O N C$ systematically appear as ${ }^{*} C,{ }_{e}{ }^{*} C$ : Rom. ${ }^{*} E N C,{ }^{*} O N C \rightarrow$ Sl. ${ }^{*} C,{ }_{e}{ }^{*} C$ (Lat. Parentium $>$ Balk. Rom. *Parentí $>*$ Parenču $\rightarrow$ Sl. *Poręč $>$ C Čak. Porëč 'a town in Istria'; Lat. Carantanum $>$ Balk. Rom. *Karantānu $\rightarrow$ Sl. *Korqtanъ $>$ Sln. Korotän 'Carinthia'). Note, however, that strictly speaking these equations only prove that during the integration of such sequences into South Slavic the latter must surely have had nasal elements, but it is not entirely clear whether these nasal elements should be interpreted as bi-phonemic sequences ${ }^{*} E N C,{ }^{*} O N C$ or rather as already fully developed nasal vowels $*_{e} C,{ }^{*} C$.

\subsection{Progressive palatalization of velars}

Old Romance $*_{k},{ }^{*} g$ after front vowels were reflected in South Slavic as $*_{c}$ and $*_{3}$, respectively: Rom. ${ }^{* E} k,{ }^{* E} g \rightarrow \mathrm{Sl} .{ }^{*} c,{ }^{*}$ (Lat. Longaticum $>$ Balk. Rom. *Longātẹu

6 One possible exception is Lat. Poetovio $>$ Balk. Rom. *Petouiu $\rightarrow$ Sl. ${ }^{*}$ Pbtujb $>$ Sln. Ptúj. It is probable that the Slavs encountered this place name earlier than the names of other settlements on the Adriatic coast and elsewhere in the Balkans. 
$\rightarrow$ Sl. *Lqgatbcb $>$ Sln. Logatac; Lat. Serdica > Balk. Rom. *Serdẹka $\rightarrow$ Sl. *Serdbcb $>$ CS Srěd $b c b$ (an old denomination of present-day Sofia)). It seems likely that these sequences were borrowed before the Slavic progressive palatalization of velars took place.

\subsection{Delabialization of $* \overline{\boldsymbol{u}}_{1}>* \boldsymbol{y}$}

Slavic *y is normally substitutued for Old Romance $* \bar{u}$ : Rom. ${ }^{*} \bar{u} /{ }^{*} \bar{\varphi} \rightarrow$ Sl. ${ }^{*} y$ (Lat. *Alluvium $>$ Balk. Rom. *Allūviu $\rightarrow$ Sl. *Olybb $>$ Čak. Olïb 'an island in the Zadar archipelago'; Lat. *Glemōna (ca. 610 in Glemona) > Alp. Rom. *Glemộna (> Friulian Glemone $) \rightarrow$ Sl. *Glbmynz > Dial. Sln. Gumín 'a town in Friuli; Standard Sln. Gumin, Friulian Glemone, It. Gemona'; Lat. Salōna > Balk. Rom. *Salọna $\rightarrow$ Sl. *Solynz > Čak. Solin 'a town in Southern Dalmatia'). This type of substitution clearly points to the fact that the Proto-Slavic process of delabialization of $* \bar{u}_{l}$ towards $* y$ postdates the earliest Romance-Slavic language contacts.

\subsection{Labialization of * $a>* o$}

Old Romance $*_{a} a$ is matched by South Slavic ${ }^{*}$ : Rom. ${ }^{*} a \rightarrow$ Sl. ${ }^{*} o$ (Lat. Aquilèia $>$ Alp. Rom. *Agolèia (> Friulian Aolèe > Olèe arch.) $\rightarrow$ Sl. *Ogъlějb $>$ Sln. Oglèj 'a town in Friuli'; Lat. Capra $>$ Balk. Rom. *Kapra $\rightarrow$ Sl. *Koprb $>$ Sln. Kópər 'a town in Istria'; Lat. Cattarum $>$ Balk. Rom. *Kattaru $\rightarrow$ Sl. *Kotorb $>$ Štok. Kòtor 'a town in Montenegro'). The typically Slavic sound change $*_{a}>*_{o}$ clearly reflects a later, Common Slavic process.

\subsection{Vowel reduction of $*_{i}, *^{*}>*_{b}, *_{b}$}

Old Romance $*_{e},{ }^{*} o$ are reflected as Slavic ${ }^{*},{ }^{*}$ : Lat. ${ }^{*} / *^{*},{ }^{*} u / *_{o}>$ Rom. ${ }^{*} e, *_{o} \rightarrow$ Sl. ${ }^{*} b,{ }^{*}{ }_{b}$ (Lat. turris 'tower' $\rightarrow$ Balk. Rom. ${ }^{*}$ Torre $\rightarrow$ Sl. ${ }^{*}$ Tъrr $>$ C Cak. Tär 'a town in Istria'; Lat. Muccurum > Balk. Rom. *Mokkoru $\rightarrow$ Sl. *Mъkъrb $>$ Čak. Makär 'a town in Southern Dalmatia'; Lat. Asg Tergeste $(m)>$ Balk. Rom. *Tergeste $\rightarrow$ Sl. *Tbrzbstb, Gsg *Tbrzbsta $>$ Sln. *Tarzast $\geq$ Tarst, Gsg *Tarzsta $>$ Tarsta 'a coastal town in Northern Istria; Italian Trieste'; Lat. Asg Pinguente $(m)>$ Balk. Rom. *Pengente $\geq *$ Pẹlgente (with dissimilation $\left.{ }^{*} n-n \geq l-n\right) \rightarrow \mathrm{Sl} .{ }^{*} \boldsymbol{B} \boldsymbol{b}$ l3etr $>$ Dial. Sln. (Istria) Buzet, Čak. Buzet 'a town in Istria'; Lat. Ad Portulam $>$ Balk. Rom. *Adportola $\rightarrow$ Sl. *Opbrtbĺb $>$ Čak. Oprtalj 'a town in Istria'; Lat. *Curicum ( $\leftarrow$ gr. Kov́pıкov) $>$ Balk. Rom. *Korẹku $\rightarrow$ Sl. *Kъrbkb > Čak. Kr̈k 'an island in the Gulf of Kvarner'). The Proto-Slavic vowel reduction of the type $*_{i}, *_{u}>*_{b}, *_{b}$ surely is a much later process.

\subsection{Liquid metathesis}

Old Romance sequences ${ }^{*} C a R C,{ }^{*} C e R C$ (where $\left.* R=* r,{ }^{*}\right)$ ) are reflected as Slavic /*CoRC, ${ }^{*} \mathrm{CeRC} /\left[{ }^{*} \mathrm{CaRC},{ }^{*} \mathrm{CeRC}\right]:$ Rom. ${ }^{*} \mathrm{CaRC},{ }^{*} \mathrm{CeRC} \rightarrow \mathrm{Sl} . /{ }^{*} \mathrm{CoRC},{ }^{*} \mathrm{Ce} \mathrm{RC} /$ [ ${ }^{*} \mathrm{CaRC},{ }^{*} \mathrm{CeRC}$ ] (Lat. Arba $>$ Balk. Rom. *Arba $\rightarrow$ Sl. *Orbb $>$ Čak. Räb 'an island in the Gulf of Kvarner'; Lat. *Albanta $>$ Balk. Rom. *Albanta $\rightarrow$ Sl. *Olbotb $>$ Sln. Lábot (860 ad Labantam) 'a town in the Jauntal/Podjuna Valley in Southern Carinthia/ Koroška, Germ. Lavamünd'; Lat. *Carsum $>$ Balk. Rom. *Karsu $\rightarrow$ Sl. *Korsb $>$ Sln. 
Kräs 'a region in the Slovene coastal area'; Lat. Scardōna $>$ Balk. Rom. *Skardọna $\rightarrow$ Sl. *Skordynz > Čak. Skradĩn 'a town in Central Dalmatia'; Lat. Syrmium > Balk. Rom. * Sermium (?) $\rightarrow$ Sl. *Sermb $>$ Štok. Srijêm, Srêm 'a region to the east of the Croation region of Slavonia'; Lat. Melita $>$ Balk. Rom. ${ }^{*}$ Melta $\rightarrow$ Sl. ${ }^{*}$ Meltb $>$ Štok. Mljët 'an island in Southern Dalmatia'). The analysed material unambiguously points to the fact that liquid metathesis followed in the wake of the first Slavic-Romance contacts.

\section{CONCLUSION}

The analysis of Old Romance place names integrated into early South Slavic shows that the majority of the late Proto-Slavic sound changes were still in progress at the time of the first Old Romance-Slavic language contacts. On the other hand, Slavic subtitutions $*_{c}, *_{3}$ and $*_{o v C}$ for the Romance sequences $* k^{E}, *^{E}$ and $* a u C$, respectively, point to the fact that two characteristic processes, i.e. the first regressive palatalization of velars and monophthongization, had already been completed. The progression of the remaining set of late Proto-Slavic (or better Common Slavic) sound changes was either contemporary with the oldest integrations or it may have postdated the earliest Romance-Slavic contacts altogether. 


\begin{tabular}{|c|c|c|c|}
\hline \multicolumn{2}{|c|}{ (Balkan) Romance } & \multirow{2}{*}{$\begin{array}{l}\text { (Proto-)Slavic } \\
*_{\mathrm{S}} \\
\end{array}$} & \multirow{2}{*}{$\begin{array}{l}\text { Examples } \\
\text { Rom. *Apsaru } \rightarrow \text { S1. *Osorb }\end{array}$} \\
\hline *ps & $\rightarrow$ & & \\
\hline$* \overline{\mathrm{u}}$ & $\rightarrow$ & $*_{\mathrm{vy}}$ & Rom. ${ }^{*} \overline{\boldsymbol{U}} d e ̣ n u \rightarrow$ Sl. ${ }^{*}(\boldsymbol{V}) \boldsymbol{y} d b n z$ \\
\hline *ki & $\rightarrow$ & $* \check{c}$ & Rom. *Dorāki $u \rightarrow$ Sl. *Dbračb \\
\hline *gi & $\rightarrow$ & $*_{\mathrm{Z}}$ & Rom. *Plāgín $\rightarrow$ Sl. *Plaža \\
\hline *si & $\rightarrow$ & $* \check{s}$ & Rom. *Arsi্ $\rightarrow$ Sl. *Ořs $a$ \\
\hline *ni & $\rightarrow$ & *ń & Rom. *Karniu $u \rightarrow$ Sl. *Korńb \\
\hline *li & $\rightarrow$ & $* 1$ & Rom. *Kastẹliộne $\rightarrow$ Sl. *Kostbluns \\
\hline *ri & $\rightarrow$ & $*_{\dot{r}}^{\prime}$ & Rom. *Tragūrinu $\rightarrow$ Sl. *Trogyŕb \\
\hline$* \mathrm{C}^{\prime} \overline{\mathrm{u}}$ & $\rightarrow$ & $* \mathrm{C}^{\prime} \mathrm{i}$ & 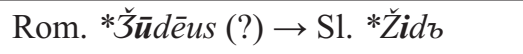 \\
\hline *rọ & $\rightarrow$ & $*$ ri & Rom. ${ }^{*} \boldsymbol{R} \overline{\boldsymbol{o}} m a \rightarrow$ Sl. ${ }^{*} \boldsymbol{R i m} b$ \\
\hline$* \mathrm{au} C$ & $\rightarrow$ & *ovC & Rom. *Laurentiu $\rightarrow$ Sl. *Lovręčb \\
\hline$* \mathrm{k}^{\mathrm{E}}$ & $\rightarrow$ & $* c^{E}$ & Rom. *Kelẹia $\rightarrow$ S1. ${ }^{*}$ Celbje \\
\hline$* g^{\mathrm{E}}$ & $\rightarrow$ & $*_{3}{ }^{\mathrm{E}}$ & Rom. ${ }^{*} \boldsymbol{G} \bar{l} l a \rightarrow$ S1. *3ila \\
\hline$* \mathrm{ENC}$ & $\rightarrow$ & $* \mathrm{e} C$ & Rom. *Parentiu $\rightarrow$ Sl. *Poręčb \\
\hline *ONC & $\rightarrow$ & $*_{\mathrm{Q}} \mathrm{C}$ & Rom. *Karantānu $\rightarrow$ Sl. *KorQtans \\
\hline$* \mathrm{ikV}$ & $\rightarrow$ & $*_{\mathrm{bcV}}$ & Rom. ${ }^{*}$ Longātiku $\rightarrow$ Sl. ${ }^{*}$ Legatbcb \\
\hline$* \overline{\mathrm{u}} / *_{\overline{0}}$ & $\rightarrow$ & $* \mathrm{y}$ & Rom. *Allūvin $\rightarrow$ S1. *Olybb \\
\hline$* \mathrm{a}$ & $\rightarrow$ & $*_{0}$ & Rom. *Kapra $\rightarrow$ Sl. *Koprb \\
\hline $\mathrm{i}>*_{\mathrm{e}}$ & $\rightarrow$ & $*_{\mathrm{b}}$ & Rom. *Korẹ̣u $\rightarrow$ S1. *Kbrıkb \\
\hline $\mathrm{u}>*_{0}$ & $\rightarrow$ & $*_{\mathrm{b}}$ & Rom. ${ }^{*}$ Torre $\rightarrow$ Sl. ${ }^{*}$ Tъrb \\
\hline$*(\mathrm{C}) \mathrm{aRC}$ & $\rightarrow$ & $*(\mathrm{C}) \mathrm{oRC}$ & Rom. *Karsu $\rightarrow$ Sl. *Korsb \\
\hline$* \mathrm{CeRC}$ & $\rightarrow$ & $* \mathrm{CeRC}$ & Rom. ${ }^{*}$ Melta $\rightarrow$ Sl. ${ }^{*}$ Melt $b$ \\
\hline
\end{tabular}

Table 1: Late Proto-Slavic sound changes through the prism of Old Romance place names borrowed into early South Slavic.

\section{Literatura}

BEZLAJ, France $(1976,1982,1995,2005,2007)$ Etimološki slovar slovenskega jezika. I-V. Ljubljana: Slovenska akademija znanosti in umetnosti, Inštitut za slovenski jezik ZRC SAZU.

BOČEK, Vít (2009) "Hláskové substituce v nejstarších romanismech ve slovanských jazycích." Studia etymologica Brunensia 6. 59-65.

BOČEK, Vít (2010) Studie k nejstarším romanismuim ve slovanských jazycích. Studia etymologica Brunensia 9. Praha: Lidové noviny. 
FURLAN, Metka (2002) “Predslovanska substratna imena v slovenščini." Jezikoslovni zapiski 8/2, 29-35.

GIMBUTAS, Marija (1971) The Slavs. London: Thames and Hudson.

GREENBERG, Marc L. (2000) A Historical Phonology of the Slovene Language. Heidelberg: Universitätsverlag Winter.

GRAD, Anton (1958) "Contribution au problème de la sonorisation des consonnes intervocaliques latines." Linguistica 3/2, 33-40.

GRAD, Anton (1969) "Importance de quelques toponymes slovènes pour la géographie linguistiques romane." Actes du Xe Congrès de Linguistique et Philologie Romanes (Strasbourg, 1962) III. Paris, 1176-1184.

HOLZER, Georg (1995) "Die Einheitlichkeit des Slavischen um 600 n. Chr. und ihr Zerfall." Wiener Slavistisches Jahrbuch 41, 55-89.

HOLZER, Georg (2007) Historische Grammatik des Kroatischen: Einleitung und Lautgeschichte der Standardsprache. Frankfurt am Main, Berlin, Bern, Bruxelles, New York, Oxford, Wien: Peter Lang.

KOS, Milko (1955) Zgodovina Slovencev od naselitve do petnajstega stoletja. Ljubljana: Slovenska matica.

RAMOVŠ, Fran (1926/27) "O prvotnih južsl. substitucijah za balk.-lat. $k, g$ pred $e$, i." Južnoslovenski filolog VI, 153-165.

RAMOVŠ, Fran (1936) Kratka zgodovina slovenskega jezika I. Ljubljana: ZRC SAZU. REPANŠEK, Luka (2014) Keltski prežitki v slovenski toponimiji: Prispevek $k$ metodologiji preučevanja. Doktorska disertacija. Filozofska fakulteta Univerze v Ljubljani. $280 \mathrm{pp}$.

SHEVELOV, George Y. (1964) A Prehistory of Slavic: The Historical Phonology of Common Slavic. Heidelberg: Carl Winter Universitätsverlag.

SKOK, Petar (1926) "Zur Chronologie der Palatalisierung von $c, g, q u, g u$ vor $e, i, y, i$ im Balkanlatein.” Zeitschrift für romanische Philologie 46, 385-410.

SKUBIC, Mitja (2002, $\left.{ }^{1} 1988\right)$ Romanski jeziki. Ljubljana: Filozofska fakultera Univerze v Ljubljani, Oddelek za romanske jezike in književnosti.

SKUBIC, Mitja $\left({ }^{4} 2007,{ }^{1} 1989\right)$ Uvod v romansko jezikoslovje. Ljubljana: Filozofska fakulteta Univerze v Ljubljani, Oddelek za romanske jezike in književnosti.

SNOJ, Marko (2003, $\left.{ }^{1} 1997\right)$ Slovenski etimološki slovar. Ljubljana: Modrijan.

SNOJ, Marko (2009) Etimološki slovar slovenskih zemljepisnih imen. Ljubljana: Modrijan, Založba ZRC.

SNOJ, Marko, GREENBERG, Marc L. (2012): “O jeziku slovanskih prebivalcev med Donavo in Jadranom v srednjem veku (pogled jezikoslovcev)." Zgodovinski časopis 66/3-4. 276-305.

SOLTA, Georg Renatus (1980) Einführung in die Balkanlinguistik mit besonderer Berücksichtigung des Substrats und des Balkanlateinsichen. Darmstadt: Wissenschaftliche Buchgesellschaft.

ŠANJEK, Franjo (ed.) (2003) Povijest Hrvata. 1. Srednji vijek. Zagreb: Školska knjiga. ŠEGA, Agata (1998) "Contributo alla conoscienza dei latinismi e romanismi antichi in sloveno." Linguistica 38/2, 63-85. 
ŠEGA, Agata (2007) "Nekaj ugotovitev o glasovnih značilnostih vulgarnolatinskih predlog za starejše latinizme in romanizme v slovenščini." Jezikoslovni zapiski $13 / 1-2,397-408$.

ŠEGA, Agata (2013) "Quelques pistes pour l'investigation des traces des premiers contacts linguistique slavo-romans dans la toponymie slovène." Linguistica 53/1, $17-29$.

ŠEKLI, Matej (2009) "On Romance-Alpo-Slavic substitutional accentology: the case of the pre-Slavic masculine substrate place names in Slovene." In: Th. Olander/J. H. Larsson (eds.), Stressing the past: papers on Baltic and Slavic accentology. Amsterda: Rodopi, 145-160. (Studies in Slavic and general linguistics, 35.)

ŠEKLI, Matej (2012) "Notranja delitev neprevzetega in prevzetega besedja v praslovanščini." In: P. Stankovska, M. Wtorkowska, J. Pallay (eds.), Individualna in kolektivna dvojezičnost. Ljubljana: Filozofska fakulteta Univerze v Ljubljani, Oddelek za slavistiko. 369-381. (Slavica Slovenica, 1.)

ŠEKLI, Matej (2013) "Metodologija določanja plasti mlajših romanizmov v slovenščini." Jezikoslovni zapiski 19/2, 291-315.

ŠEKLI, Matej (2014) Primerjalno glasoslovje slovanskih jezikov 1: Od praindoevropščine do praslovanščine. Ljubljana: Znanstvena založba Filozofske fakultete.

ŠEKLI, Matej (2015) "Staroromanska zemljepisna imena v južni slovanščini in poznopraslovanske glasovne spremembe." Philological Studies 13/1. 333-343.

ŠIMUNOVIĆ, Petar (2005) Toponimija hrvatskoga jadranskog prostora. Zagreb: Golden marketing-Tehnička knjiga.

ŠTIH, Peter, SIMONITI, Vasko (2009) Na stičišču svetov: Slovenska zgodovina od prazgodovinsih kultur do konca 18. stoletja. Ljubljana: Modrijan.

ŠTURM, Fran (1927) "Refleksi romanskih palataliziranih konzonantov v slovenskih izposojenkah." Časopis za slovenskih jezik, književnost in zgodovino 6, 45-85.

ŠTURM, Fran (1928) "Romanska lenizacija medvokaličnih konzonantov in njen pomen za presojo romanskega elementa v slovenščini.” Časopis za slovenski jezik, književnost in zgodovino 7, 21-46.

TEKAVČIĆ, Pavao (1970) Uvod u vulgarni latinitet. Zagreb: Sveučilište u Zagrebu.

UDOLPH, Jürgen (1979) Studien zu slavischen Gewässernamen und Gewässerbezeichnungen: Ein Beitrag zur Frage nach der Urheimat der Slaven. Heidelberg: (ar) Winter Universitäts Verlag.

VON WARTBURG, Walther(1950) Die Ausgliederung der romanischen Sprachräume. Bern: Francke. 


\section{Summary \\ OLD ROMANCE PLACE NAMES IN EARLY SOUTH SLAVIC AND LATE PROTO-SLAVIC SOUND CHANGES}

The analysis of Old Romance geographical names in early South Slavic confirms that the majority of late Proto-Slavic sound changes were still operative in the period of the earliest Old Romance-Slavic language contacts in the Balkan Peninsula and eastern Alps from the second half of the $6^{\text {th }}$ century and the beginning of the $7^{\text {th }}$ century onwards. Phonetic substitutions of the type Rom. ${ }^{*} k^{E},{ }^{*} g^{E} \rightarrow$ Sl. ${ }^{*} c,{ }^{*} 3$ (Balk. Rom. ${ }^{*}$ Kersu $\rightarrow$ Sl. *Cersz, Balk. Rom. *Gila $\rightarrow$ Sl. *3iĺa) and Rom. *auC $\rightarrow$ Sl. *ovC (Balk. Rom. *Laurentiu $>{ }^{*}$ Laurenču $\rightarrow$ Sl. * Lovręčb) point to the fact that the first palatalization of velars as well as the monophthongization of the inherited diphthongs were no longer among the ongoing processes. All other late Proto-Slavic sound changes were either still operative or only took place after the borrowing. This is confirmed by the relative chronology of the following set of Romance-Slavic correspondences: simplification of consonant clusters: Rom. ${ }^{*} p s \rightarrow$ Sl. $*_{s}$ (Balk. Rom. *Apsaru $\rightarrow$ Sl. ${ }^{*}$ Osorb), development of prothetic consonants: Rom. ${ }^{*} \bar{u}-\rightarrow$ Sl. ${ }^{*} u \bar{u}->*_{v y-}$ (Alp. Rom. $* \bar{U}$ dẹn $\rightarrow$ Sl. $\left.{ }^{*}(V) y d b n z\right)$, simplification of j-clusters: Rom. ${ }^{*} C i \rightarrow$ Sl. ${ }^{*} C^{\prime}$ (Balk. Rom. *Arsia $\rightarrow$ Sl. *Orša), delabialization of $*^{*} \overline{\text { after }} *^{*}$ : Rom. ${ }^{*} r \bar{o} \rightarrow \mathrm{S} 1 . *_{r y}>*_{r i}$ (Rom. *Rọma $\rightarrow \mathrm{Sl}$. *Rymb $>*$ Rimb), second regressive palatalization of velars (see above Sl. ${ }^{*}$ Cersb, ${ }^{*}$ 3ilía), rise of nasal vowels: Rom. ${ }^{*} E N C,{ }^{*} O N C \rightarrow \mathrm{Sl} .{ }^{*} e C,{ }^{*}{ }_{Q} C$ (Balk. Rom. *Parentiu $>{ }^{*}$ Parenču $\rightarrow$ Sl. *Poręčb, Balk. Rom. *Karantānu $\rightarrow$ Sl. ${ }^{*}$ Korqtanb), progressive palatalization of velars: Rom. ${ }^{* E} k,{ }^{* E} g \rightarrow \mathrm{Sl} .{ }^{*} c,{ }^{*}{ }_{3}$ (Balk. Rom. *Longātẹku $\rightarrow$ S1. *LQgatbcb), delabialization of $*^{*} \bar{u}_{1}>*^{*} y:$ Rom. ${ }^{*} \bar{u} /{ }^{*} \bar{q} \rightarrow \mathrm{S} 1 .{ }^{*} y$ (Balk. Rom. *Allūviu $\rightarrow$ Sl. $\left.{ }^{*} O l y b z\right)$, labialization of $* a>*_{o}$ : Rom. ${ }^{*} a \rightarrow$ Sl. ${ }^{*} o$ (Balk.

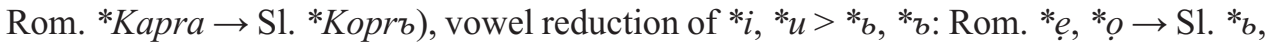
$*_{\text {* }}$ (Balk. Rom. *Korẹu $\rightarrow$ Sl. ${ }^{*}$ Kъrbkъ, Balk. Rom. *Torre $\rightarrow$ Sl. *Tbrb).

Keywords: Old Romance geographical names, Old Romance, South Slavic, ProtoSlavic, Proto-Slavic sound changes

\section{Povzetek \\ STAROROMANSKA ZEMLJEPISNA IMENA V ZGODNJI JUŽNI SLOVANŠČINI IN POZNOPRASLOVANSKE GLASOVNE SPREMEMBE}

Glasoslovna analiza staroromanskih zemljepisnih imen v zgodnji južni slovanščini potrjuje, da je bila večina poznopraslovanskih glasovnih sprememb v času najstarejših romansko-slovanskih jezikovnih stikov na Balkanskem polotoku in vzhodnih Alpah v drugi polovici 6. stoletja in v začetku 7. stoletja še vedno v teku. Glasovni substituciji tipa rom. ${ }^{*} k^{E},{ }^{*} g^{E} \rightarrow$ sl. ${ }^{*} c,{ }^{*} 3$ (balk. rom. ${ }^{*}$ Kersu $\rightarrow$ sl. ${ }^{*}$ Cersb, balk. rom. ${ }^{*} G i ̄ l a \rightarrow$ sl. *3ila) in rom. *auC $\rightarrow$ sl. ${ }^{*}$ ovC (balk. rom. *Laurentiu $>*^{*}$ Laurenču $\rightarrow$ sl. *Lovręčb) potrjujeta, da starejša regresivna (prva) palatalizacija velarov in monoftongizacija diftongov nista bili več v teku. Vse ostale poznopraslovanske glasovne spremembe pa so 
ali bile $\mathrm{v}$ teku ali pa je do njih prihajajo po prevzemanju, kar potrjujejo naslednje romansko-slovanske glasovne substitucije, in sicer poenostavitev soglasniških sklopov: rom. *ps $\rightarrow$ sl. *s (balk. rom. *Apsaru $\rightarrow$ sl. *Osorb), nastanek protetičnih drsnikov: rom. ${ }^{*} \bar{u}$ - $\rightarrow$ sl. ${ }^{*} u \bar{u}->{ }^{*} v y$ - (alp. rom. ${ }^{*} \bar{U} d e ̣ n u \rightarrow$ sl. $\left.{ }^{*}(V) y d b n ъ\right)$, jotacija: rom. ${ }^{*} C i \rightarrow$

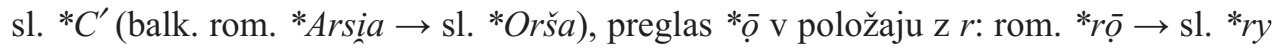

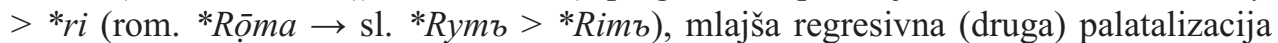
velarov (prim. zgoraj sl. $\left.{ }^{*} C e r s z,{ }^{*} 3 i l i a\right)$, nazalizacija: rom. ${ }^{*} E N C,{ }^{*} O N C \rightarrow$ sl. ${ }^{*} C$, ${ }^{*} Q C$ (balk. rom. *Parentiu $>{ }^{*}$ Parenču $\rightarrow$ sl. ${ }^{*}$ Poręčb, balk. rom. ${ }^{*}$ Karantānu $\rightarrow$ sl. ${ }^{*}$ Korotanъ), progresivna (tretja) palatalizacija velarov: rom. ${ }^{* E} k,{ }^{* E} g \rightarrow$ sl. ${ }^{*} c,{ }^{*}{ }_{3}$ (balk. rom. ${ }^{*}$ Longāte $k u \rightarrow$ sl. ${ }^{*}$ Legatbcb), delabializacija of ${ }^{*} \bar{u}_{1}>{ }^{*} y:$ rom. ${ }^{*} \bar{u} /{ }^{*} \bar{o} \rightarrow$ sl. ${ }^{*} y$ (balk. rom. ${ }^{*}$ Allūviu $\rightarrow$ sl. ${ }^{*}$ Olybb), labializacija $* a>*^{*}$ : rom. ${ }^{*} a \rightarrow$ sl. ${ }^{*} o$ (balk. rom. ${ }^{*}$ Kapra $\rightarrow$ sl. ${ }^{*}$ Koprz), redukcija $*_{i}, *_{u}>{ }^{*}$, ${ }_{b}$ : rom. $*_{e}, *_{o} \rightarrow$ sl. ${ }^{*}{ }_{b},{ }^{*}{ }_{b}$ (bak. rom. ${ }^{*}$ Korẹ $k u \rightarrow$ sl. ${ }^{*}$ Kъrbkъ, balk. rom. ${ }^{*}$ Torre $\rightarrow$ sl. ${ }^{*}$ Tъrb).

Ključne besede: staroromanska zemljepisna imena, stara romanščina, južna slovanščina, praslovanščina, praslovanske glasovne spremembe 